\title{
Personalistyczne ujęcie w wychowaniu „kładkq" ku budowie kultury opartej na wartościach
}

\section{Personalistic Approach in Education as a Way for Developing Culture Based on Values}

\begin{abstract}
ABSTRAKT
Artykuł przedstawia analizę wybranych myśli przedstawicieli filozofii egzystencjalnej oraz filozofii dialogu, ze szczególnym uwzględnieniem poglądów J. Tischnera, T. Gadacza oraz M. Bubera, w celu ukazania, iż dzięki personalistycznemu podejściu w wychowaniu możliwa jest budowa kultury zasadzającej się na takich wartościach, jak wolność, dialog, szacunek, tolerancja, miłość. W celu mocnego podkreślenia, jak ważna jest rola personalizmu w wychowaniu, ukażę jego przeciwieństwo na bazie pogladów wypracowanych przez badaczkę "czarnej pedagogiki” Alice Miller, która przedstawia, jak destruktywne dla dziecka, a w szerszym ujęciu dla kultury jest traktowanie jednostki przedmiotowo i stosowanie wobec niej przemocy. W przygotowaniu pracy wykorzystałam głównie metodę analizy materiałów zastanych oraz metodę syntezy. Centralne kategorie, wokół których prowadzone sq badania, to: dziecko, wychowanie, personalizm, wolność, przemoc. Personalizm konstytuuje eksponowanie osoby jako istoty autonomicznej, jei godności i rozumności. Z kolei „czarna pedagogika" nawiqzuje do badań nad wpływem przemocy psychicznej na umysł dziecka. Stosowanie mechanizmów represjonowania dzieci w okresie dzieciństwa prowadzi do ogromnych zniszczeń, jakie
\end{abstract}

SPI Vol. 22, 2019/2

ISSN 2450-5358

e-ISSN 2450-5366

DOI: 10.12775/SPI.2019.2.010

Nadestano: 20.03.2019

Zaakceptowano: 21.05.2019

Miscellanea 
dokonuja się w człowieku, jak i w kulturze, w kłórej żyje. Wychowanie oparte na personalistycznym podejściu do człowieka jest dla ludzkości kluczem do budowy kultury opartej na wartościach: wolności, dialogu, szacunku, tolerancji, miłości.

\section{ABSTRACT}

The article presents an analysis of the selected thoughts of existential philosophers and philosophers of dialogue, with particular emphasis on the views of J. Tischner, T. Gadacz and M. Buber, to show that thanks to the personalistic approach in education, it is possible to build a culture based on values such as freedom, dialogue, respect, tolerance and love. In order to emphasize the personalism, I will show views worked out by the researcher of "black pedagogy" - Alice Miller, who presents how destructive violence experienced during childhood is for a child, and in a wider perspective, for the culture. In my preparation of the issue, I used the method of the analysis of existing materials and the synthesis method. The central categories around which the considerations are conducted are: child, education, freedom, violence. Personalism emphasizes a person as an autonomous human being, its dignity and rationality. In turn, "black pedagogy" refers to research on the influence of mental violence on the child's mind. Using mechanisms of repression in their childhood leads to tremendous human and cultural deterioration. An education based on a personalistic approach in education is the key to building a culture based on freedom, dialogue, respect, tolerance, love.

\section{Wprowadzenie}

Celem niniejszego artykułu jest ukazanie, że niezwykle istotnym zadaniem ludzkości jest budowanie kultury opartej na takich wartościach, jak tolerancja, szacunek, wolność, miłość. Piszę o zadaniu, ponieważ kultura w całej swej wielowymiarowości nie jest czymś danym, ale właśnie zadanym. Źródeł urzeczywistnienia tego zadania poszukuję na płaszczyźnie wychowania w ujęciu personalistycznym. Od zarania dziejów człowiek budował wielkie cywilizacje, torował nowe drogi sobie i światu, dokonywał oszałamiających wynalazków i odkryć, tworzył wspaniałe dzieła sztuki, jak również niszczył zastaną 
równowagę natury, wszczynał wojny, dotykał dna hańby i upodlenia, wreszcie szykował totalną zagładę sobie i światu. Emmanuel Levinas reprezentujący filozofię dialogu stwierdził, że wraz z Auschwitz wolność została całkowicie skompromitowana, a zniewolenie zarówno zewnętrzną formą autorytarną jak i wewnętrznymi pobudkami człowieka osiągnęło swoje apogeum:

Po raz pierwszy w historii byt ludzki nic nie znaczy. Nie jest to wróg, z którym trzeba walczyć, więzień, którego można wymienić. Jest przedmiotem do zniszczenia. Nazistowski horror nie wynika $z$ nienawiści takiej lub takiej jakości, lecz z nienawiści do innego człowieka ${ }^{1}$.

Odnoszę się tutaj do przytoczonego cytatu, ponieważ daje on obraz okrutnej rzeczywistości XX wieku, którą ukształtował nie kto inny, tylko człowiek. Od człowieka zależy zatem, w jakiej rzeczywistości będzie bytował, ale tę rzeczywistość należy najpierw uformować w taki sposób, aby mógł kształtować siebie oraz kulturę na drodze wartości.

W pracy wykorzystałam metodę analizy materiałów zastanych oraz metodę syntezy. Poprzez pryzmat poglądów wypracowanych przez Alice Miller ukażę, jak destruktywna dla dziecka, a w szerszym ujęciu dla kultury jest stosowana w dzieciństwie przemoc. W głównej mierze przedstawię poglądy filozofów egzystencjalnych oraz filozofów dialogu, ze szczególnym uwzględnieniem myśli J. Tischnera, T. Gadacza oraz M. Bubera, które uważam za kulturowy fundament, na którym powinniśmy oprzeć dzisiejsze wychowanie. Kultura stanowi wyraz, świadectwo, fenomen życia duchowego jednostki i u podstaw jej zaistnienia leży wola człowieka, uruchamiana przez jego osobowe Ja. Źródło tkwi więc w człowieku, który dzięki wychowaniu do wolności ma szansę i możliwość budowania kultury dialogu, tolerancji, szacunku, miłości.

\section{Istota wychowania}

Wychowanie we współczesnym ujęciu, z perspektywy antropologicznej, jest procesem całożyciowym, a więc stanowi taki fenomen

1 T. Gadacz, Wolność a odpowiedzialnośc. Rosenzweiga i Levinasa krytyka Heglowskiej wolności ducha, Kraków 1998, s. 86. 
ludzkiej egzystencji, który nie podlega jego wyborowi. Każdy człowiek jest skazany na proces wychowania. Doświadczenie bycia wychowywanym każdy nosi we własnym doświadczeniu egzystencjalnym i jest nim niejako napiętnowany w podstawowej sferze życia psychicznego i duchowego. Na podstawie tego doświadczenia buduje własną interpretację świata, która staje się po latach kanwą jego sposobu odnoszenia się do drugiego człowieka oraz umiejętności postrzegania spraw z myślą o dobru konkretnych ludzi². Proces wychowania zależy w dużej mierze od czasu historycznego, społecznego oraz biograficznego. Nie toczy się on w próżni, ale przebiega zawsze w konkretnym i złożonym kontekście. Uczestnicy procesu wychowania zanurzeni są w różnorakich procesach społecznych, które to procesy stwarzają warunki oraz wyznaczają parametry: materialne, kulturalne, polityczne i inne dla przebiegu wychowania. To, w jakim stopniu rytm procesu wychowania pokrywa się, a w jakim rozchodzi z rytmem życia również wpływa na przebieg wychowania i jego skuteczność ${ }^{3}$.

Idąc za myślą K. Ablewicz uwrażliwiam czytelnika, że mimo zmieniających się warunków zewnętrznych, determinowanych przez czas historyczny, społeczny czy biograficzny należy poszukiwać „aksjologicznej stałej antropologicznej”", która będzie wiązać pokolenia i utrzymywać sens paidei. W. Stróżewski rozumie aksjologiczne a priori jako ideę stawania się człowiekiem, tj. ideę człowieczeństwa. W łacińskiej idei humanitas spotyka się filozofia i paideia; pierwsza, by ją odsłaniać, druga, by wedle niej kształtować człowieka. Idea człowieczeństwa od czasów starożytnych przyświecała refleksji nad człowiekiem: ,jak wielką rzeczą jest człowiek, gdy jest człowiekiem”, aż po czasy współczesne, kiedy mówimy: „człowiek to brzmi dumnie”.

2 K. Ablewicz, Cztowiek jako metodologiczny problem pedagogiki, „Horyzonty Wychowania” 2002, nr 1, s. 87.

3 P. Sztompka, Czas spoteczny, czas biograficzny, czas pedagogiczny, „Zeszyty Naukowe Uniwersytetu Jagiellońskiego. Prace Pedagogiczne” 1987, z. 6, s. 91-93.

4 Por. K. Ablewicz, Cztowiek jako metodologiczny problem pedagogiki, dz. cyt., s. 101.

5 W. Stróżewski, O stawaniu się cztowiekiem, kilka myśli niedokończonych, „Zeszyty Naukowe Uniwersytetu Jagiellońskiego. Prace Pedagogiczne”1987, z. 6, s. 37.

6 Tamże. 
Wartość człowieczeństwa zakłada, że człowiek stoi wobec wartości i na realizację tych wartości jest niejako skazany, jeśli tylko chce być człowiekiem. Tezę tę odzwierciedla choćby słynna myśl św. Augustyna w zdaniu: „Stworzyłeś nas, Panie, dla siebie i niespokojne jest serce nasze, póki nie spocznie w Tobie"7, jak również stojące ponad wszystko prawo moralne Kanta. Stawanie się człowiekiem zawsze dokonuje się w jakiejś sytuacji, dzieje się w nim samym, jak i wobec czegoś. Owo „wobec” ma wiele odsłon, od stosunku do kosmosu, stosunku do Boga, aż do bytu jako bytu, do Bycia. Heidegger widzi w tej odsłonie istotny budulec humanitas. Gdzie zatem należy upatrywać aksjologicznego a priori? Być może właśnie w przekraczaniu siebie, budowaniu człowieka w sobie, ale nie tylko dla siebie, lecz dla drugiego człowieka. Na płaszczyźnie Ty i Ja możliwa jest realizacja najpiękniejszych wartości dobra i piękna. Tragizm wychowania polega jednak na tym, że wartości aktualizowane w człowieku są bytowo kruche, najbardziej nietrwałe i nigdy nie można z całą pewnością stwierdzić, iż zakorzeniły się w człowieku już na zawsze ${ }^{8}$. Zatem należy w sposób możliwie prawdziwy, autentyczny kierować procesem wychowania. Idąc za myślą J. Tischnera można powiedzieć, że wiedza o wartościach pozbawiona aksjologicznego poczucia rzeczywistości konkretnej sytuacji jest jedynie moralizowaniem, a tym samym klęską wychowania. Nie zawsze ważne jest, by wszystko wiedzieć, ale istotne jest, by potrafić przekroczyć siebie, by w jakiejś sytuacji po prostu „przy kimś być” 9 . Dopełnieniem powyższej filozofii będzie rozumienie wychowania przez K. Ablewicz czy T. Gadacza następująco: „Wychowanie musi, z samej istoty życia społecznego, być zawsze wychowaniem do wolności i dla twórczości”10. Jeżeli zabraknie w procesie wychowania powyższych wartości, człowiek będzie powielał model destruktywnego wychowania, a tym samym destruktywnych zachowań. Jeżeli wychowanie będzie równoznaczne

7 A. Kijowski, Dopiski do „Wyznañ” św. Augustyna, „W Drodze” 1985, nr 3, s. 155 .

8 W. Stróżewski, O stawaniu się cztowiekiem, kilka myśli niedokończonych, dz. cyt., s. 36-41.

9 J. Tischner, Etyka wartości i nadziei, w: D. von Hildebrand, J.A. Kłoczowski, J. Paściak, J. Tischner, Wobec wartości, Poznań 1984, s. 96.

10 Por. P. Sztompka, Czas spoteczny, czas pedagogiczny, czas biograficzny, dz. cyt., s. 94 . 
z zabijaniem zdrowych instynktów życiowych dziecka, to uniemożliwi nie tylko jego prawidłowy rozwój, ale nieosiągalny staje się cel budowy kultury miłości i wolności.

\section{"CZarna pedagogika" - myśl Alice Miller}

Zaprzeczeniem idei wychowania wedle takich wartości, jak wolność, twórczość, miłość, szacunek, tolerancja przedstawiła A. Miller w książce Zniewolone dzieciństwo. Ukryte zródta tyranii ${ }^{11}$. Zapoczątkowała ona nurt w pedagogice zwany „czarną pedagogiką" ${ }^{12}$, który obejmował kierunek badań nad wpływem przemocy psychicznej na umysł dziecka. Poglądy A. Miller zwróciły uwagę na negatywny wpływ określonych teorii i praktyk wychowawczych, utrwalających w kolejnych pokoleniach formy i mechanizmy represjonowania dzieci. W swojej książce ukazuje ona, jak istotny jest wpływ traktowania dziecka we wczesnych latach jego życia na jego późniejszy rozwój i zachowania. Analizując dzieciństwo trzech osób, tj. Christiany F., Adolfa Hitlera oraz Jürgena Bartscha, Miller przedstawia obraz zniszczeń, jakich dokonuje w człowieku przemoc oraz płynące stąd zagrożenia społeczne. Przytaczam w swojej pracy poglądy tej autorki, ponieważ wraz z całym okrucieństwem, które ukazuje w swojej książce, daje ona również nadzieję, iż człowiek może zmienić otaczającą go rzeczywistość. Zmiana możliwa będzie tylko wówczas, kiedy ludzkość zdobędzie się na poznanie przyczyn otaczającego ją zła.

Pierwsza z przytoczonych przez A. Miller historii to biografia dzieciństwa Christiany F., dziewczynki, która przez cały okres swojego początkowego życia doznawała przemocy zarówno fizycznej,jak i psychicznej. Christiana nieustannie narażona była na nieprzewidywalne bicie ze strony ojca. Jej zachowanie z czasem przybrało formę: „dać ojcu dobre powody do lania”"13, które miało na celu usprawiedliwianie jego zachowania. Christiana F. w swojej książce $M y d z i e c i$ $z$ dworca $Z O O$ pisze: „Nigdy go przecież nie nienawidziłam, ja się go tylko bałam. No i zawsze byłam z niego dumna. Bo kochał zwierzęta

\footnotetext{
11 A. Miller, Zniewolone dzieciństwo. Ukryte źródta tyranii, przeł. B. Przybyłowska, Poznań 1999.

12 Tamże, s. 25.

13 Tamże, s. 130.
} 
i miał taki ekstra wóz, porsche z 62 roku" ${ }^{14}$. Uderzający w tym zdaniu jest tragizm sytuacji dziecka, które nie dość że doznało krzywdy, to tej krzywdy nie mogło wykrzyczeć, nie mogło nienawidzić swego prześladowcy, wręcz przeciwnie - musiało go kochać i szanować. Najczęściej występującym mechanizmem obronnym dziecka w powyższej sytuacji jest wyparcie zrozumiałej nienawiści do ojca z własnej świadomości i zmagazynowanie jej w nieświadomości. Christiana poprzez ciągłe upokorzenia, których doznawała, wypowiada początkowo wojnę innym autorytetom męskim, a całą nagromadzoną nienawiść kieruje przeciw własnemu Ja. Systematycznie niszczy własną godność poprzez popadnięcie w nałóg narkotykowy, stopniowo skazując się na odosobnienie i milczenie, przez co rujnuje zarówno swoje ciało jak i ducha. A. Miller porównuje życie Christiany do sytuacji, w jakiej znalazł się więzień obozu koncentracyjnego. Podkreśla jednak, że sytuacja maltretowanego dziecka jest gorsza i poważniejsza w skutkach dla społeczeństwa i kultury aniżeli sytuacja osoby dorosłej w obozie koncentracyjnym. Więzień obozu nie będzie nigdy wątpił w tragizm własnych przeżyć, tak samo nie będzie nigdy traktował wyrządzonego mu cierpienia jako koniecznego środka wychowawczego, ani też nie będzie wzbraniał się przed nienawiścią wobec swojego oprawcy. Będzie mógł podzielić się swoimi uczuciami oburzenia, nienawiści, rozpaczy. Takiej możliwości nie ma maltretowane dziecko. Dziecko zmuszane do zabijania w sobie swoich naturalnych, spontanicznych uczuć nauczy się je w sobie dławić, by ostatecznie całkowicie się ich wyrzec.

$\mathrm{Z}$ doświadczeń psychoanalitycznych A. Miller wynika, że siły duchowe zawsze muszą mieć swoje ujście, bo inaczej zawsze będą to wypaczone, niebezpieczne formy. Jedną z nich może być projekcja własnej dziecięcości na świat zewnętrzny, inną może być skierowanie całego zła przeciwko sobie, jak to się stało z Christianą.

Pojawiająca się na każdym polu nieczułość na cierpienia z okresu własnego dzieciństwa bierze swoje źródło właśnie w mechanizmie zabijania spontanicznych uczuć u dziecka. Co więcej, skutki owego wyzucia z wszelkich emocji prowadzą do tego, że jest się niezwykle nieczułym na cierpienie innych ludzi. Jeżeli przez całe dzieciństwo

14 Christiane F., My dzieci z dworca ZOO, przeł. R. Turczyn, Warszawa 1987, s. 24. 
dziecko wierzy, iż krzywdę, którą mu wyrządzono, zrobiono dla jego dobra, wówczas wierzy również, że należy akceptować takie postępowanie jako niezbędny element życia. Adolf Hitler napisał:

Moje zasady wychowania są twarde. Słabość należy zgnieść. W warownych twierdzach mojego zakonu wyrośnie młodzież, która przerazi świat. Chcę młodzieży silnej, władczej, nieulękłej, okrutnej. Taka właśnie ma być ta młodzież. Musi znosić ból. Nie wolno jej mieć w sobie nic słabego i kruchego. Z ich oczu ma wyglądać wolna, władcza, dzika bestia. Chcę młodzieży silnej i pięknej.W ten sposób będę mógł stworzyć nowy świat ${ }^{15}$.

Korzeni tych słów, jak i wszechogarniającej nienawiści Hitlera wobec Żydów, osób chorych umysłowo i innych ludzi należy wedle A. Miller upatrywać właśnie w przemocy, jakiej doznawał w dzieciństwie.Przytoczony powyżej cytat z książki Adolfa Hitlera Mein Kampf jest odbiciem wszystkich reguł i zasad w jego domu. Struktura jego rodziny została porównana do ustroju totalitarnego, tak usilnie wdrażanego w życie w całej Europie przez Hitlera. Jego ojciec był brutalnym władcą domu, któremu musieli podporządkować się wszyscy domownicy. Sam Adolf pisze o swoim ojcu: „pan ojciec"16. Musiał całkowicie dostosować się do woli ojca, do jego nastrojów i kaprysów, co oznaczało pokorne znoszenie upokorzeń i niesprawiedliwości. Najważniejszą dewizą ojca Adolfa było całkowite posłuszeństwo. Od najwcześniejszych lat Hitler uczył się przyjmować okrucieństwa wychowania jako karę za własne przewinienia, a tym samym uczył się bycia silnym i zarazem okrutnym. Nic nie miało wpływu na codzienną chłostę. Pozostawało mu tylko zaciskanie zębów, by nie okazać bólu. Adolf musiał wyprzeć się samego siebie i identyfikować się z prześladowcą.

Stan ciągłego zagrożenia Hitler powielił w swoich rządach wśród miliona ludzi. Tak jak trzyletnie dziecko, tak później Żyd nie miał żadnego wpływu na to, co podsunie akurat fantazja funkcjonariuszowi SS. Jego ojciec nigdy nie przywoływał go imieniem, tylko pstryknięciem $\mathrm{w}$ palce, co można porównać $\mathrm{z}$ bezimiennym oraz wyjętym spod wszelkich praw statusem Żyda w Trzeciej Rzeszy. Hitler nienawidził Żydów, ponieważ nosił w sobie niedozwoloną nienawiść i pragnął zdobyć dla niej prawo legalnego istnienia.

15 A. Miller, Zniewolone dzieciństwo. Ukryte źródta tyranii, dz. cyt., s. 160.

16 Tamże, s. 161. 
Prześladowanie Żydów umożliwiło mu prześladowanie słabego dziecka we własnym ja. Uczucia, które zostały w dzieciństwie wyparte, w dorosłym życiu droga projekcji zostały przeniesione na ofiary, by nie przeżywać żadnych żalów nad przeszłym cierpieniem. Mimo podporządkowania swoim rządom niemal całej Europy, Adolf nocami popadał w stany manii prześladowczej, co A. Miller tłumaczy jako wczesnodziecięce doświadczenia przemocy ukryte na polu podświadomości. Przelanie całej nienawiści na Żydów i inne rasy nie wystarczyło, by przegnać z życia Hitlera uwewnętrznionego w nim ojca, gdyż nawet zniszczenie całego świata nie zdołałoby zniszczyć jego podświadomości zatrutej nienawiścią do ojca.

Ostatni opisany przez A. Miller przykład tego, w jaki sposób znęcanie się nad dzieckiem prowadzi do katastrofalnych skutków, ukazuje życie niejakiego Jürgena Bartscha. Chłopak ten od szesnastego do dwudziestego roku życia popełniał okrutne mordy na dzieciach. Jego dzieciństwo, podobnie jak Christiany czy Adolfa Hitlera, przesiąknięte było niedającym się pojąć okrucieństwem. Oprócz codziennej chłosty, w tym wypadku ze strony matki, więziony był w piwnicy, co odegrało w późniejszym życiu ważną rolę. Jako dorosły, Jürgen zamykał chłopców w podziemnym schronie, by tam ich zabijać. Dokonywanie morderstw to rozpaczliwa próba znalezienia ujścia dla nagromadzonej, a potępianej przez społeczeństwo nienawiści do rodziców ${ }^{17}$. Trzy przytoczone przez autorkę historie dają nam klucz do zrozumienia morderstw duchowych dokonywanych w dzieciństwie w nurcie „czarnej pedagogiki”.

Podobnie jak A. Miller wierzę, że człowiek nie rodzi się bestią, ale może się nią stać poprzez wdrażanie destruktywnych zasad wychowawczych. Daje to jednak nadzieję, że możliwe jest konstruktywne wychowanie. We współczesnych nurtach pedagogicznych wiele się zmieniło na płaszczyźnie podejścia do wychowania. Pedagogika odchodzi od zasad tradycyjnego wychowania, kierując się w stronę podejścia personalistycznego, które reprezentowali choćby E. Mounier, J. Tischner, J. Maritain, M. Buber, W. Cichoń, T. Gadacz, R. Ingar$\operatorname{den}^{18}$. Na tym właśnie polu pedagogicznym skupiam się w dalszej

17 Tamże, s. 174.

18 K. Ablewicz, Cztowiek jako metodologiczny problem pedagogiki, dz. cyt., s. 202. 
pracy, bowiem z całym przekonaniem uważam, że na wartościach tam wypracowanych opiera się fundament kultury dialogu i miłości.

\section{Personalistyczne ujęcie w wychowaniu}

Personalizm konstytuuje eksponowanie osoby jako istoty autonomicznej, jej godności i rozumności. B. Kiereś uważa, że godność człowieka nie wypływa $\mathrm{z}$ faktu jego wolności, lecz jest wpisana w jego strukturę bytową ${ }^{19}$. Personalistyczne podejście do człowieka zakłada wychowanie w duchu uznania każdej osoby jako jednostki niepowtarzalnej, indywidualnej, autonomicznej, wolnej. Osoba zawsze traktowana jest jako podmiot czyli autor własnych działań. Uznaje się jej społeczną naturę, opartą na dialogu i wspólnocie. Rozwijanie życia duchowego jednostki jawi się jako nadrzędny cel paidei ${ }^{20}$.

W relacji wychowawczej podkreśla się wzajemność i podmiotowość wszelkich oddziaływań. W zasadzie całe życie człowieka jest dialogowe ze swej natury, natomiast w procesie wychowania dialog dwóch osób jest niezwykle ważny, by dziecko w przyszłości potrafiło stawać wobec wartości. Uczestniczenie w dialogu to nic innego jak słuchanie, pytanie i odpowiadanie. Każde dziecko ma prawo wyrazić własne zdanie, pytać o rzeczy dla niego niezrozumiałe, ale też ma obowiązek nauki słuchania. Relacja wychowawcza winna zawsze mieć charakter dialogiczny, gdzie nauczyciel i uczeń otwierają się na siebie i wzajemnie na siebie oddziałują. W ujęciu personalistów człowiek staje się osobą wówczas, kiedy nawiąże relacje $\mathrm{z}$ drugą osobą. M. Buber podkreśla tę myśl w zdaniu:

Człowiek staje się Ja w kontakcie z Ty, ponieważ człowiek jako osoba jest istotą zwróconą ku drugiemu, ku innym ludziom, jest istotą dialogiczną. Dopiero w dialogu z innymi ludźmi może siebie pełniej odkrywać, rozwijać i urzeczywistniać" ${ }^{21}$.

19 B. Kiereś, Wspótczesna pedagogika a problem godności cztowieka, w: Personalistyczny wymiar filozofii wychowania, red. A. Szudra i K. Uzar, Lublin 2009, s. 188.

20 B. Śliwerski, Z perspektywy pedagogiki personalistycznej, „Edukacja i Dialog” 1996, nr 6, s. 13-18.

21 M. Buber, Ja i Ty. Wybór pism filozoficznych, przeł. J. Doktór, Warszawa 1992, s. 56 . 
Relacje międzyludzkie muszą zawsze rozpoczynać się od uznania jednostkowego istnienia każdej osoby. Osobie należy się afirmacja, nie ze względu na określone jej przymioty, ale ze względu na to, że Jest, ze względu na jej wolność. Obraz tego dał M. Buber, pisząc o spotkaniu wychowawcy z uczniami:

Oto wchodzi on po raz pierwszy do klasy, widzi ich skulonych przy stolikach, rozmieszczonych przypadkowo, źle lub dobrze zbudowanych, o twarzach pustych, zwierzęcych albo szlachetnych - ma przed sobą obecny jak gdyby stworzony wszechświat. Spojrzenie wychowawcy akceptuje i przyjmuje ich wszystkich. Nie jest on z pewnością potomkiem greckich bogów, którzy porywali swoich wybrańców. Wygląda mi raczej na przedstawiciela prawdziwego Boga. Bo jeżeli Bóg kształtuje światło i stwarza ciemność, człowiek jest zdolny to i to pokochać - pokochać światło dla niego samego i ciemność dla światła przyszłego ${ }^{22}$.

Wychowanie w ujęciu personalistycznym staje się odpowiedzią na potrzeby zmieniającej się rzeczywistości, która domaga się nieustającego rozwoju człowieka, jego doskonalenia w stawaniu się człowiekiem $^{23}$. W procesie kształtowania człowieka istotnym kierunkiem działań staje się wychowanie do wolności. Wolność jest pojęciem niezwykle trudnym do zdefiniowania. Moje przemyślenia skupiają się wokół rozumienia wolności przez J. Tischnera: ,jako sposobu istnienia dobra"24. Idąc tym śladem, człowiek odkrywa, że jest wolny, ale też doświadcza konieczności bycia odpowiedzialnym. Wolność w ujęciu J. Tischnera i T. Gadacza pojawia się dopiero w relacjach międzyludzkich. Ta relacja człowieka do człowieka określana jest przez myślicieli jako „bycie wolnym” ${ }^{25}$, bowiem związana jest ona $z$ naszym istnieniem $\mathrm{i}$ istnieniem drugiego człowieka. To, co pozwala człowiekowi wierzyć w trwałość uczuć, stałość przychylności czy dobroci, co stanowi istotę relacji międzyludzkich, to właśnie wiara w wolność drugiego człowieka i ufność pokładana w tej wolności. Szczególnie możemy to dostrzec w doświadczeniu miłości. Miłość bowiem zakłada wolność i wyklucza przymus.

M. Buber, Wychowanie, przeł. S. Grygiel, „Znak”1968, nr 166, s. 442-461.

Zob. W. Stróżewski, O stawaniu się cztowiekiem, kilka myśli niedokończonych, dz. cyt.

T. Gadacz, Wolność $i$ odpowiedzialność, http://p-ntzp.com/dok/09gadacz-p. pdf, [dostęp: 07.01.2018].

Tamże. 
Pięknym odzwierciedleniem filozofii miłości w procesie wychowania stała się myśl pedagogiczna Janusza Korczaka. Miłość wychowawcza, której tak wiele miejsca poświęcił Korczak, jest niczym innym jak skrystalizowaną postawą aksjologiczną. Według niego miłość to służba dziecku, walka o dziecko, to niezgoda wobec krzywdy i niesprawiedliwości, jakich dziecko doznawało. Korczak jako człowiek i jako pedagog całkowicie wyrażał miłość wobec swoich podopiecznych. Wielokrotnie wyznawał: „Ślubowałem i chcę trwać przy dziecku, jego sprawie [...]"26. I trwał, nawet w obliczu śmierci dzieci nie opuścił, poświęcił swoje życie dla dobra dziecka. Dla Korczaka dziecko zawsze jawiło się jako pełnoprawny, pełnowartościowy człowiek, który dla prawidłowego rozwoju potrzebuje wychowania w duchu miłości i wolności. Partnerski i odpowiedzialny stosunek wobec dziecka zakłada chęć prawdziwego poznania go. Tylko dzięki najpełniejszemu wniknięciu w psychikę i duszę dziecka możliwe jest zaistnienie mądrej, głębokiej i trwałej miłości. Tylko dzięki „uczenia się dziecka” oraz uczeniu się od dziecka widoczna staje się jego wolność, prawo do nieskrępowanego rozwoju, prawo do dzieciństwa, prawo do szczęścia. W eseju Jak kochać dziecko ${ }^{27}$ Korczak pragnie nauczyć „rozumieć i kochać” dziecko. Miłość jest wartością zadaną, którą każdy rodzic musi się nauczyć, do której dochodzi na drodze rozwiązywania problemów dziecka. Ponadto każdy wychowawca musi poznać siebie samego, własną drogę ku poznaniu dziecka. Tylko taki wychowawca będzie wyzwalał, kształtował, uczył, pytał, zamiast: wtłaczał, ciągnął, ugniatał, żądał, poniżał. Korczak oprócz moralnego nakazu podmiotowego traktowania dziecka pragnie kodyfikować tę podmiotowość w postaci praw, w tym zwłaszcza prawa do szacunku. Myśl Korczaka jest ciągle żywa i autentyczna. Warto bliżej przyjrzeć się filozofii wychowania zaproponowanej przez Korczaka, bowiem wskazuje jak dążyć do tolerancji, dialogu, demokracji ${ }^{28}$.

Wracając do zagadnienia wychowania do wolności, należałoby prócz pytania o to, w jaki sposób rozumiemy wolność, zapytać: dlaczego mielibyśmy wychowywać do czegoś, co przecież jest istotą człowieka? Wolność wymaga wychowania, bowiem niełatwo jest

J. Korczak, Jak kochać dziecko. Prawo dziecka do szacunku, Warszawa 2006.

27 Tamże, s. 87.

28 Tamże, s. 158. 
podejmować decyzje, być wolnym. T. Gadacz podkreśla, że człowiek, który walczy o wolność, tęskni do niej jak do zakazanego owocu. W momencie, kiedy ją uzyska, doświadcza jej ciężaru, samotności i odpowiedzialności. Dlatego łatwo z niej rezygnuje i ucieka. W sposób genialny przedstawił to doświadczenie $\mathrm{E}$. Fromm w swoim dziele Ucieczka od wolności. Ukazał w nim człowieka pragnącego uciec od wolności, która stała się zniewoleniem wewnętrznym. Jednostka stała się ofiarą lęku przed wolnością, zgodziła się wyrzec własnego indywidualnego ,ja” na rzecz podporządkowania się nowym formom autorytetu, co dało jednostce poczucie siły, której sama nie posiadała, bądź upodobnienia się do obowiązujących wzorców, co z kolei zapewniło jednostce poczucie miejsca w strukturze społecznej ${ }^{29}$. Jednostka, by mogła poczuć się wolną, by tę wartość doceniała i nie traktowała jako filozofii doraźnej przyjemności, potrzebuje wychowania do wolności. Muszą zaistnieć takie warunki, w których dziecko będzie podejmowało własne decyzje, będzie odpowiedzialne za i wobec, i w tej odpowiedzialności doświadczy własnej tożsamości. Wychowanie do wolności jest wychowaniem do odwagi bycia wolnym, bowiem człowiek w swoich wyborach i decyzjach pozostaje samotny i z tą samotnością musi się zmierzyć. Wolność człowieka przejawia się w jego twórczym działaniu. Wychowanie do wolności zakłada więc wychowanie do samodoskonalenia poprzez twórcze poznanie samego siebie i wykształcenie zdolności do wolnej ekspresji twórczej. Poprzez czyn twórczy jednostka wyraża i poznaje samego siebie, odkrywając swoją osobową tożsamość i doświadczając, że jej czyny są wolne, ponieważ są jej czynami. Należy jednak w tym miejscu zaznaczyć, że twórcze czyny wolności nie są spełniane w aksjologicznej pustce. Człowiek dokonuje wyborów, aby urzeczywistnić wartość (pozytywną bądź negatywną). Wolność nie pojawia się w świecie czystych możliwości, ale w świecie wartości: dobra i zła, szczęścia i nieszczęścia, prawdy i nieprawdy. Człowiek musi być wolny wobec zasad moralnych czy wartości.

Jednostka posiada wolną wolę, zatem może wybrać przykładowo bycie zarówno sprawiedliwą, jak i niesprawiedliwą. Wola jest więc wolna dwojako: po pierwsze wobec determinacji przyczynowych s. 56 . 
praw świata, po drugie wobec wartości. Sens wolności ukazuje się w jej afirmacji dla niej samej, urzeczywistnienie jej ze względu na nią samą. Wychowanie do wolności zakłada więc świadomość istnienia antynomii, a wręcz dramatu. Dlatego wychowanie do wolności musi być zawsze wychowaniem antyautorytarnym. Wartości stoją wolnością, co oznacza, że nie mogą zostać urzeczywistnione na drodze przymusu. Tylko wolny rodzic, pedagog jest zdolny do afirmacji wolności dziecka, wychowanka. Jak stwierdził J. Korczak: „Nie możemy zmienić naszego życia dorosłych, bośmy sami wychowani w niewoli, nie możemy dać dziecku swobody dopóki samiśmy w kajdanach" ${ }^{30}$. Wartość wolności musi być w sposób żywy obecna w dojrzałych etycznie osobach. Bowiem tylko ten, kto ma szacunek dla siebie, ma go również dla innych. Tylko ten, kto jest wolny, jest zdolny uznać wolność drugiego. Tylko ten, kto umie władać sobą, potrafi również władać innymi ${ }^{31}$. Zaznaczam jednak, że wolność nie jest ostatecznym celem wychowania, jest natomiast siłą, która daje wolne pole budowaniu piękna i dobra. Jak to ujął T. Gadacz, jest „kładką, po której się przechodzi, ale na której się nie mieszka" ${ }^{32}$. Kładką ku tworzeniu więzi, które będą nośnikiem wartości: więź przyjacielska, więź braterska, więź rodzicielska. Wychowanie do wolności pozwala każdemu doświadczać siebie jako osoby oraz innych osób, z którymi tworzy więź i przynależność. Tożsamość, która wyłania się z twórczej wolności, przejawia się w tożsamości z rodzicami, przyjaciółmi, rodzeństwem, z którymi dzięki wolności pozostajemy związani ${ }^{33}$.

\section{Zakończenie}

Reasumując jeszcze raz podkreślam, jak ważne jest podejście personalistyczne w procesie wychowania. Afirmacja osoby taką jaka ona jest, stworzenie warunków do twórczego działania i poznawania samego siebie, przygotowanie do odpowiedzialnych osobistych wyborów, wychowanie do wolności i odpowiedzialności, wychowanie $\mathrm{w}$ duchu miłości - to jedne $\mathrm{z}$ najważniejszych aksjologicznych

J. Korczak, Jak kochać dziecko. Prawo dziecka do szacunku, dz. cyt., s. 156.

T. Gadacz, Wychowanie do wolności, „Znak” 1993, nr 460 (9), s. 106.

32 Tamże, s. 107.

33 Tamże, s. 97-106.
} 
aspektów procesu pedagogicznego, dające szansę pokojowego współistnienia, budowy kultury zasadzającej się na takich wartościach, jak: wolność, miłość, dialog, szacunek, tolerancja. Jakże różnią się one od form wychowawczych zaprezentowanych w książce Alice Miller Zniewolone dziecinstwo. Ukryte źródta tyranii. Zdemaskowanie mechanizmu przemocy w rodzinie odsłoniło przerażający obraz maltretowania dziecka oraz skutki tej przemocy. Żyjemy w cywilizacji, która okalecza ludzką wolność i świadomość. Człowiek ulega różnorakim ideologiom, które stawiają jednostkę w miejsce Boga, fałszywą tolerancję w miejsce prawdy, kruche relacje w miejsce miłości. Filozofia postmodernizmu wypacza ludzkie pragnienia, ideały i aspiracje, by człowiek coraz więcej miał, a mniej był kochającym, dojrzałym i wolnym. Efektem tego jest popularyzowanie życia prymitywnego, opartego na tym, co kto posiada, a nie na tym, kim ktoś się staje. Kultura budowana poza miłością, prawdą, wolnością, odpowiedzialnością staje się podłożem cywilizacji uzależnień, cywilizacji śmierci ${ }^{34}$.

\section{Bibliografia}

Ablewicz K., Cztowiek jako metodologiczny problem pedagogiki, „Horyzonty Wychowania” 2002, nr 1, s. 87-202.

Buber M.,Ja i Ty. Wybór pism filozoficznych, przeł.J. Doktór, „Pax”, Warszawa 1992.

Buber M., Wychowanie, przeł. S. Grygiel, „Znak” 1968, nr 166, s. 442-461.

Christiane F., My dzieci z dworca ZOO, przeł. R. Turczyn, Wydawnictwo Iskry, Warszawa 1987.

Dziewiecki M., Wychowanie a wolność, https://opoka.org.pl/biblioteka/I/IP/ wolosc.html [dostęp: 09.01.2018].

Fromm E., Ucieczka od wolności, przeł. O. i A. Ziemilscy, Czytelnik, Warszawa 2007.

Gadacz T., Wolność a odpowiedzialnośc. Rosenzweiga i Levinasa krytyka Heglowskiej wolności ducha, Papieska Akademia Teologiczna w Krakowie, Kraków 1998.

GadaczT., Wolnośćiodpowiedzialność,http://p-ntzp.com/dok/09gadacz-p.pdf [dostęp: 07.01.2018].

Gadacz T., Wychowanie do wolności, „Znak” 1993, nr 460 (9), s. 97-107. 
Kiereś B., Wspótczesna pedagogika a problem godności cztowieka, w: Personalistyczny wymiar filozofi wychowania, red. A. Szudra i K. Uzar, Wydawnictwo KUL, Lublin 2009, s. 188.

Kijowski A., Dopiski do „Wyznañ” św. Augustyna, „W Drodze” 1985, nr 3.

Korczak J., Jak kochać dziecko. Prawo dziecka do szacunku, Czarna Owca, Warszawa 2006.

Miller A., Zniewwolone dzieciństwo. Ukryte źódta tyranii, przeł. B. Przybyłowska, Media Rodzina, Poznań 1999.

Stróżewski W., O stawaniu się cztowiekiem, kilka myśli niedokończonych, „Zeszyty Naukowe Uniwersytetu Jagiellońskiego. Prace Pedagogiczne” 1987, z. 6, s. 36-41.

Sztompka P., Czas spoteczny, czas biograficzny, czas pedagogiczny, „Zeszyty Naukowe Uniwersytetu Jagiellońskiego. Prace Pedagogiczne” 1987, z. 6, s. 91-94.

Śliwerski B., Z perspektywy pedagogiki personalistycznej, „Edukacja i Dialog” 1996, nr 6, s. 13-18.

Tischner J.,Etyka wartości i nadziei, w: D. von Hildebrand, J.A. Kłoczowski, J. Paściak, J. Tischner, Wobec wartości, W drodze, Poznań 1984, s. 96.

\section{ADRES DO KORESPONDENCJI}

Mgr Barbara Geneja-Pietrzak

Akademia Ignatianum w Krakowie

Wydział Filozoficzny

Instytut Kulturoznawstwa

e-mail: geneja.barbara@gmail.com 